\title{
ВПЛИВ ГОСТРОЇ КРОВОВТРАТИ, УСКЛАДНЕНОЇ ІШЕМІЄЮ-РЕПЕРФУЗІЄЮ КІНЦІВКИ, НА ДИНАМІКУ ПОКАЗНИКІВ ЕНЗИМНОЇ ЛАНКИ АНТИОКСИДАНТНОГО ЗАХИСТУ В СЕЛЕЗІНЦІ ТА ЙОГО КОРЕКЦІЯ КАРБАЦЕТАМОМ
}

\author{
Тернопільський національний медичний університет імені І. Я. Горбачевського МОз України
}

РЕЗЮМЕ. Порушення ензимної ланки антиоксидантного захисту належить до одного з ключових патогенних механізмів ураження внутрішніх органів за умов гострої крововтрати та ішемічно-реперфузійного синдрому. Однак порушення активності супероксиддисмутази (СОД) та каталази за умов гострої крововтрати та ії ускладнення ішемією-реперфузією кінцівки в селезінці практично не досліджені. Немає даних про ефективність за цих умов карбацетаму, який має антиоксидантну і тканинопротекторну активність.

Мета - з' ясувати особливості порушень показників ензимної ланки антиоксидантної системи в селезінці щурів після гострої крововтрати, ускладненої ішемією-реперфузією кінцівки, та ефективність її корекції карбацетамом.

Матеріал і методи. В експериментах використано 108 нелінійних щурів-самців масою 200-220 г. Усі експерименти виконані під тіопентало-натрієвим наркозом. У тварин моделювали ішемію-реперфузію кінцівки, гостру крововтрату та поєднували ці ушкодження. В окремій групі проводили корекцію виявлених порушень карбацетамом. Через 1 і 2 години, а також через 1, 7 і 14 діб у селезінці піддослідних тварин визначали активність СОД та каталази.

Результати. Моделювання гострої крововтрати, ускладненої ішемією-реперфузією кінцівки, в селезінці сприяє найбільшому виснаженню СОД і каталази. Починаючи з 1 год експерименту активність цих ферментів стає істотно меншою, порівняно з тваринами дослідної групи, в якій моделювали лише гостру крововтрату. Застосування карбацетаму суттєво знижувало порушення активності СОД і каталази в селезінці вже після 7-денного застосування. Показники були ще більшими після введення карбацетаму протягом 14 діб, що вказує на виражений протективний вплив препарату на досліджувані чинники антиоксидантного захисту селезінки і $\epsilon$ перспективним засобом системної корекції.

Висновки. 1. Двогодинна ішемія кінцівки внаслідок застосування кровоспинного джгута за умов гострої крововтрати сприяє істотним зниженням активності СОД і каталази в селезінці з максимумом через 1 добу, величина якої не повертається до рівня контролю через 14 діб. Уведення карбацетаму протягом 7-14 діб супроводжується вираженим протекторним впливом на стан ензимної ланки антиоксидантного захисту селезінки.

КЛЮчОВІ СлОВА: гостра крововтрата; ішемія-реперфузія кінцівки; селезінка; супероксиддисмутаза; каталаза; карбацетам.

Вступ. Активація процесів ліпідної пероксидації належить до одного з ключових патогенних механізмів гострої крововтрати й зумовлена, з одного боку, розвитком гіпоксії та накопиченням активних форм оксигену (АФО), з іншого - виснаженням антиоксидантного захисту [1]. За цих умов виникають передумови для переокиснення ліпідів і білків клітинних мембран, що може викликати їх деструкцію з посиленням ендотоксикозу та розвитком поліорганної недостатності [2, 3].

В умовах гострої крововтрати єдиним засобом порятунку $є$ застосування кровоспинних джгутів з граничним терміном накладання до двох годин [4]. В роботах окремих авторів показано, що двогодинне повне знекровлення кінцівки в реперфузійному періоді здатне викликати активацію процесів ліпідної пероксидації в сироватці крові та внутрішніх органах, яке компенсується до 14 доби чинниками антиоксидантного захисту [5]. Однак за умов одночасної гострої крововтрати додаткова ішемія-реперфузія кінцівки посилює пероксидне окиснення ліпідів і поглиблює порушення антиок- сидантного захисту $[6,7]$, зокрема ензимної ланки: супероксиддисмутази (СОД) та каталази - першого рубежу знешкодження АФО.

У наших попередніх дослідженнях показано, що за умов гострої крововтрати та ішемії-реперфузії кінцівки порушення ПОЛ виникають і в селезінці [8] - органі, який за рахунок депонувальної функції може впливати на стан центральної гемодинаміки й одночасно стимулювати еритропоез [9]. Однак активність ензимної ланки антиоксидантного захисту за умов гострої крововтрати та її ускладнення ішемією-реперфузією кінцівки в селезінці практично не досліджено. Немає даних про ефективність за цих умов карбацетаму, який, за даними окремих авторів [6], має антиоксидантну активність і виявив позитивний вплив на стан внутрішніх органів.

Мета - з'ясувати особливості порушень показників ензимної ланки антиоксидантної системи в селезінці щурів після гострої крововтрати, ускладненої ішемією-реперфузією кінцівки, та ефективність корекції карбацетамом. 
Огляди літератури, оригінальні дослідження, погляд на проблему, випадок з практики, короткі повідомлення

Матеріал і методи дослідження. В експериментах використано 108 нелінійних щурів-самців масою 200-220 г. Усі експерименти виконано з дотриманням правил «Європейської конвенції захисту хребетних тварин, яких використовують 3 експериментальною та іншою науковою метою» (European Convention, 1984).

Піддослідних тварин поділили на п'ять груп: контрольну та чотири дослідних (по 6 щурів у групі). Усі втручання виконані за умов тіопентало-натріє-

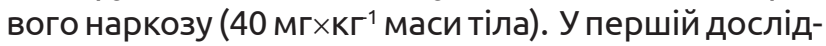
ній групі тваринам моделювали ішемію-реперфузію кінцівки шляхом накладання проксимально на ліву лапку джгута протягом 120 хв. Застосовували смужку еластичного джгута "SWAT-T» (США) завширшки 10 мм. Такий джгут має мінімальний негативний вплив на підлеглі тканини і забезпечує сталу повну ішемію впродовж терміну експерименту [10]. У другій дослідній групі моделювали гостру крововтрату в обсязі 20-22 \% об'єму циркулюючої крові шляхом пересікання стегнової вени. У третій дослідній групі ці ушкодження поєднували. У четвертій дослідній групі тваринам із гострою крововтратою, ускладненою ішемією-реперфузією кінцівки, з метою корекції внутрішньоочеревинно вводили карбацетам (Інститут фізико-органічної хімії і вуглехімії імені Л. М. Литвиненка НАН України, Київ) в дозі 5 мг на кілограм маси тварини [6].

В умовах тіопентало-натрієвого наркозу тварин першої, другої і третьої дослідних груп виводили з експерименту через 1 і 2 години, а також через 1, 7 і 14 діб, тварин четвертої дослідної групи - через 7 і 14 діб. У контрольній групі тварин лише вводили в наркоз, застосовуючи еквівалентну дозу тіопенталу натрію, накладали джгут без припинення кровотоку і в подальшому виводили з експерименту через 2 год.

Для досліджень брали селезінку, в гомогенаті якої визначали активність СОД (КФ 1.1.15.1.) [11] і каталази (КФ 1.11.1.6) [12]. Вірогідність відмінностей між контрольною і дослідними групами оцінювали з використанням непараметричного критерію Манна -Уїтні.

Результати й обговорення. Дослідження показали, що внаслідок моделювання ішемії-реперфузії кінцівки активність СОД у селезінці зростала, порівняно з контролем (табл. 1), що було статистично вірогідним починаючи з 2 год експерименту й досягало максимуму через 7 діб (у 3,92 раза, $\mathrm{p}<0,05)$. Після гострої крововтрати показник, навпаки, знижувався, що ставало істотно меншим вже через 2 год експерименту (на 23,4 \%, p<0,05) й залишалося на такому ж рівні до 14 доби. Водночас після поєднання гострої крововтрати та ішемії-реперфузії кінцівки порушення були більш вираженими. Активність СОД у селезінці знижувалася й досягала мінімуму через 1 добу експерименту (на 60,5 \%, p<0,05) й залишалася на такому ж рівні до 14 доби.

Порівняння дослідних груп показало, що через 1 год показник, за умов поєднання ішемії-реперфузії кінцівки та гострої крововтрати, був істотно меншим, ніж після моделювання лише ішемії-реперфузії кінцівки (на 21,0 \%, $\mathrm{p}_{1-3}<0,05$ ). Починаючи з 2 год експерименту, зі збільшенням тяжкості ураження, показник ставав статистично вірогідно меншим $\left(\mathrm{p}_{1-2}<0,05, \mathrm{p}_{1-3}<0,05, \mathrm{p}_{2-3}<0,05\right)$.

Таблиця 1. Активність СОД селезінки (ум. од.мм ${ }^{-1}$ ) після гострої крововтрати, ускладненої ішемією-реперфузією кінцівки (Me (LQ; UQ) - медіана (нижній і верхній квартилі))

\begin{tabular}{|c|c|c|c|c|c|}
\hline \multirow{2}{*}{ Дослідна група } & \multicolumn{5}{|c|}{ Термін реперфузійного періоду } \\
\hline & 1 год & 2 год & 1 доба & 7 доба & 14 доба \\
\hline \multicolumn{6}{|c|}{ Контроль $=0,81(0,76 ; 0,92)(n=6)$} \\
\hline $\begin{array}{l}\text { Група } 1 \\
\text { Ішемія-реперфузія }\end{array}$ & $\begin{array}{c}0,95 \\
(0,85 ; 1,10) \\
(n=6)\end{array}$ & $\begin{array}{c}1,22^{*} \\
(1,07 ; 1,26) \\
(n=6)\end{array}$ & $\begin{array}{c}2,29^{*} \\
(2,07 ; 2,44) \\
(n=6)\end{array}$ & $\begin{array}{c}3,18^{*} \\
(3,10 ; 3,25) \\
(n=6)\end{array}$ & $\begin{array}{c}1,94^{*} \\
(1,80 ; 2,10) \\
(n=6)\end{array}$ \\
\hline $\begin{array}{l}\text { Група } 2 \\
\text { Крововтрата }\end{array}$ & $\begin{array}{c}0,86 \\
(0,75 ; 0,94) \\
(n=6)\end{array}$ & $\begin{array}{c}0,62^{*} \\
(0,57 ; 0,66) \\
(n=6)\end{array}$ & $\begin{array}{c}0,56^{*} \\
(0,40 ; 0,66) \\
(n=6)\end{array}$ & $\begin{array}{c}0,56^{*} \\
(0,52 ; 0,63) \\
(n=6)\end{array}$ & $\begin{array}{c}0,62^{*} \\
(0,57 ; 0,66) \\
(n=6)\end{array}$ \\
\hline $\begin{array}{l}\text { Група } 3 \\
\text { Ішемія-реперфузія+ } \\
\text { крововтрата }\end{array}$ & $\begin{array}{c}0,75 \\
(0,67 ; 0,81) \\
(n=6)\end{array}$ & $\begin{array}{c}0,48^{*} \\
(0,36 ; 0,53) \\
(n=6)\end{array}$ & $\begin{array}{c}0,29^{*} \\
(0,24 ; 0,32) \\
(n=6)\end{array}$ & $\begin{array}{c}0,32^{*} \\
(0,27 ; 0,37) \\
(n=6)\end{array}$ & $\begin{array}{c}0,38^{*} \\
(0,32 ; 0,43) \\
(n=6)\end{array}$ \\
\hline$P_{1-2}$ & $>0,05$ & $<0,05$ & $<0,05$ & $<0,05$ & $<0,05$ \\
\hline$P_{1-3}$ & $<0,05$ & $<0,05$ & $<0,05$ & $<0,05$ & $<0,05$ \\
\hline$P_{2-3}$ & $>0,05$ & $<0,05$ & $<0,05$ & $<0,05$ & $<0,05$ \\
\hline
\end{tabular}

Примітки. Тут і в табл. 2:

1. * - відмінності стосовно контрольної групи статистично вірогідні $(p<0,05)$;

2. р $_{1-2}$ - вірогідність відмінностей між дослідними групами 1 і 2;

3. $\mathrm{p}_{1-3}$ - вірогідність відмінностей між дослідними групами 1 і 2;

4. $\mathrm{p}_{2-3}$ - вірогідність відмінностей між дослідними групами 1 i 3. 
Огляди літератури, оригінальні дослідження, погляд на проблему, випадок з практики, короткі повідомлення

Активність каталази за умов ішемії-реперфузії кінцівки також зростала (табл. 2). Через 2 год показник перевищив контроль на 60,2 \%, через 1 добу - у 2,59 раза, через 7 діб - у 2,16 раза, через 14 діб - на 67,7 \% ( $<<0,05)$. За умов моделювання гострої крововтрати показник, порівняно з контролем, через 1 год компенсаторно зростав на 23,7 \% ( $<<0,05)$, проте в подальшому знижувався і через 2 год ставав меншим від контролю на 15,8 \%, через 1 добу - на 33,1 \%, через 7 діб - на 28,3 \%, через 14 діб - на 27,8 \% (р<0,05). Після моделювання гострої крововтрати в поєднанні з ішемією-реперфузією кінцівки активність каталази селезінки вже через 1 год експерименту статистично вірогідно знижувалася (на 23,3 \%, р<0,05). Показник досягав мінімуму через 1 добу (на 63,9 \%, р<0,05) й залишався на такому ж рівні до 14 доби.

Порівняння дослідних груп показало, що через 1 год активність каталази в селезінці була статистично вірогідно меншою у групі, в якій моделювали поєднане ушкодження, порівняно з іншими дослідними групами (відповідно на 35,4 \%, $\mathrm{p}_{1-3}<0,05$ та на 38,2\%, $\left.\mathrm{p}_{2-3}<0,05\right)$. У подальшому, як і за величиною СОД, активність каталази знижувалася відповідно до тяжкості ураження $\left(\mathrm{p}_{1-2}<0,05\right.$, $\left.\mathrm{p}_{1-3}<0,05, \mathrm{p}_{2-3}<0,05\right)$.

Таблиця 2. Активність каталази селезінки (ум. од.ммг) після гострої крововтрати, ускладненої ішемієюреперфузією кінцівки (Me (LQ; UQ) - медіана (нижній і верхній квартилі))

\begin{tabular}{|c|c|c|c|c|c|}
\hline \multirow{2}{*}{ Дослідна група } & \multicolumn{5}{|c|}{ Термін реперфузійного періоду } \\
\hline & 1 год & 2 год & 1 доба & 7 доба & 14 доба \\
\hline \multicolumn{6}{|c|}{ Контроль $=1,33(1,25 ; 1,47)(n=6)$} \\
\hline $\begin{array}{l}\text { Група } 1 \\
\text { Ішемія-реперфузія }\end{array}$ & $\begin{array}{c}1,58 \\
(1,47 ; 1,64) \\
(n=6)\end{array}$ & $\begin{array}{c}2,13^{*} \\
(2,04 ; 2,25) \\
(n=6)\end{array}$ & $\begin{array}{c}3,45^{*} \\
(3,28 ; 3,58) \\
(n=6)\end{array}$ & $\begin{array}{c}2,88^{*} \\
(2,73 ; 3,07) \\
(n=6)\end{array}$ & $\begin{array}{c}2,23^{*} \\
(1,89 ; 2,46) \\
(n=6)\end{array}$ \\
\hline $\begin{array}{l}\text { Група } 2 \\
\text { Крововтрата }\end{array}$ & $\begin{array}{c}1,65^{*} \\
(1,57 ; 1,66) \\
(n=6) \\
\end{array}$ & $\begin{array}{c}1,12^{*} \\
(1,07 ; 1,18) \\
(n=6)\end{array}$ & $\begin{array}{c}0,89^{*} \\
(0,74 ; 0,97) \\
(n=6) \\
\end{array}$ & $\begin{array}{c}0,82^{*} \\
(0,73 ; 0,87) \\
(n=6) \\
\end{array}$ & $\begin{array}{c}0,96^{*} \\
(0,90 ; 1,08) \\
(n=6) \\
\end{array}$ \\
\hline $\begin{array}{l}\text { Група } 3 \\
\text { Ішемія-реперфузія+ } \\
\text { крововтрата }\end{array}$ & $\begin{array}{c}1,02^{*} \\
(0,88 ; 1,09) \\
(n=6) \\
\end{array}$ & $\begin{array}{c}0,64^{*} \\
(0,61 ; 0,66) \\
(n=6)\end{array}$ & $\begin{array}{c}0,48^{*} \\
(0,43 ; 0,56) \\
(n=6) \\
\end{array}$ & $\begin{array}{c}0,53^{\star} \\
(0,50 ; 0,64) \\
(n=6) \\
\end{array}$ & $\begin{array}{c}0,60^{*} \\
(0,51 ; 0,66) \\
(n=6) \\
\end{array}$ \\
\hline$P_{1-2}$ & $>0,05$ & $<0,05$ & $<0,05$ & $<0,05$ & $<0,05$ \\
\hline$p_{1-3}$ & $<0,05$ & $<0,05$ & $<0,05$ & $<0,05$ & $<0,05$ \\
\hline$P_{2-3}$ & $<0,05$ & $<0,05$ & $<0,05$ & $<0,05$ & $<0,05$ \\
\hline
\end{tabular}

Застосування карбацетаму (рис. 1) протягом 7 і 14 діб приводило до збільшення активності
СОД у селезінці - відповідно на 65,6 і 28,3 \% $(p<0,05)$.

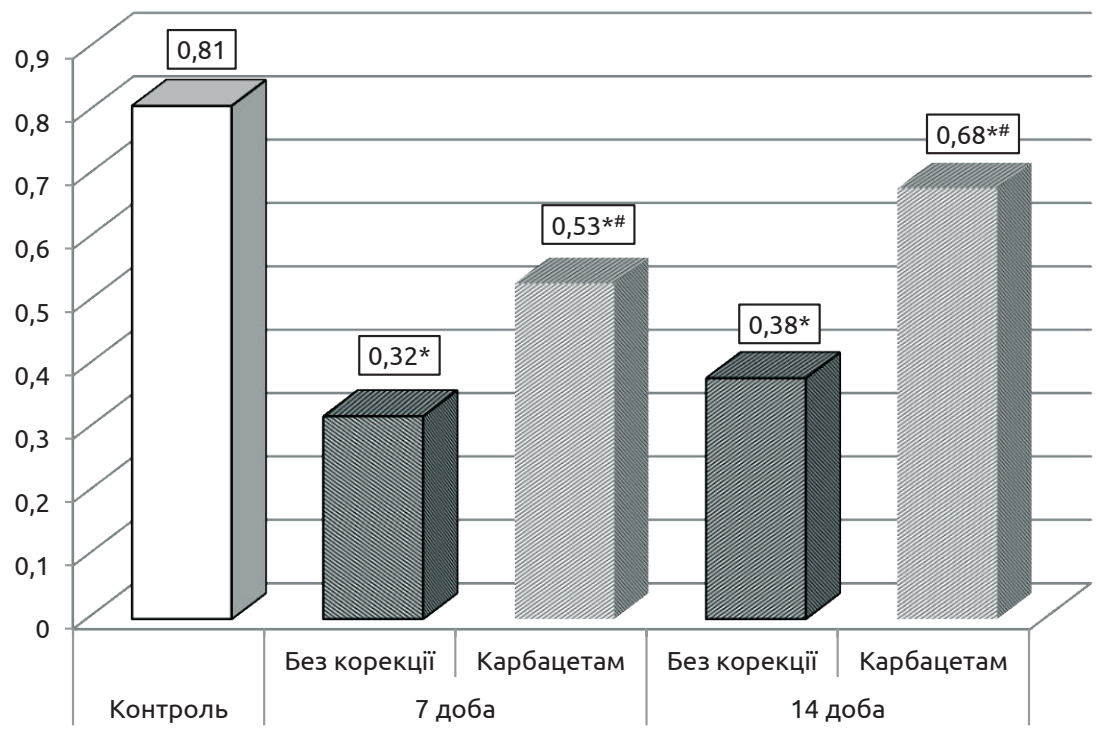

Рис. 1. Вплив карбацетаму на активність СОД (ум. од. $м \Gamma^{-1}$ ) після гострої крововтрати, ускладненої ішемієюреперфузією кінцівки. (Примітка. Тут і на рис. 2: * - відмінності стосовно контрольної групи статистично вірогідні, p<0,05; \# - відмінності стосовно групи без корекції статистично вірогідні, $p<0,05)$. 
Огляди літератури, оригінальні дослідження, погляд на проблему, випадок з практики, короткі повідомлення

Під впливом карбацетаму збільшувалася й активність каталази (рис. 2): відповідно на 84,9 і $75,05(p<0,05)$.

Отримані результати свідчать про те, що за умов моделювання лише ішемії-реперфузії кінцівки активність СОД та каталази у гомогенаті селезінки зростала, що ставало статистично значущим починаючи з 2 год експерименту, до- сягало максимуму через 1 добу та не досягало рівня контролю до 14 доби. Таке зростання, очевидно, має компенсаторний характер у відповідь на зростання активності процесів ПОЛ у селезінці. Останнє, як свідчать дані окремих авторів, зумовлене прооксидантними ендотоксинами, які надходять з кінцівки після ії̈ реперфузiї $[13,14]$.

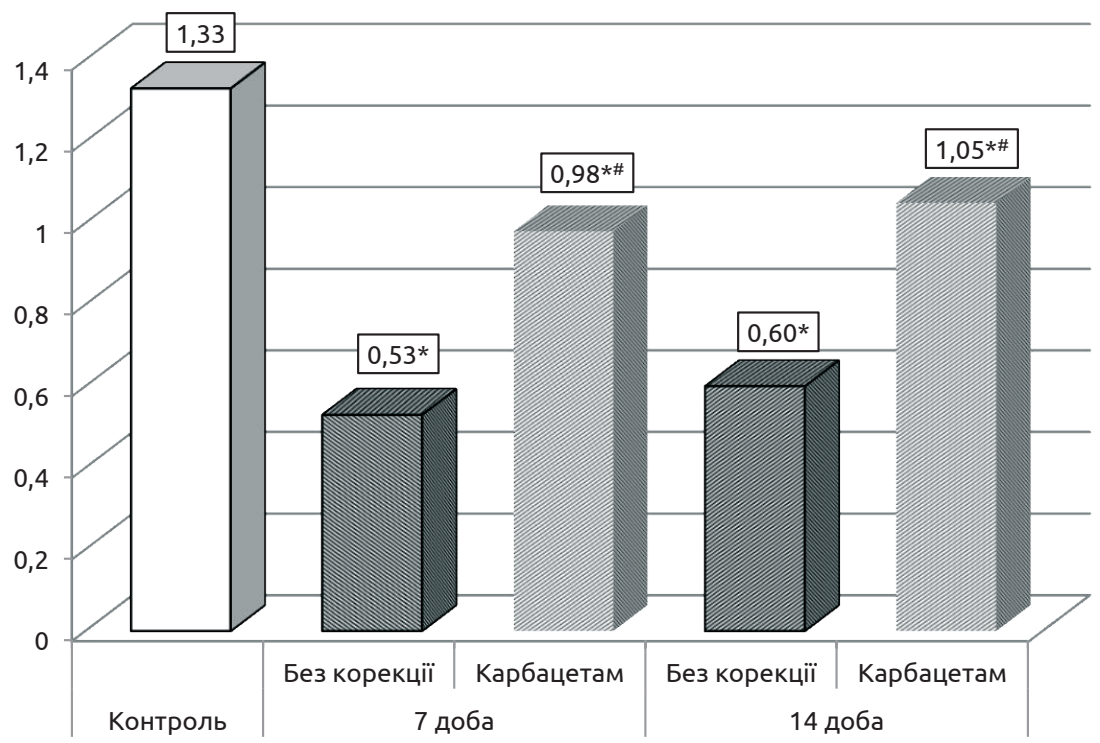

Рис. 2. Вплив карбацетаму на активність каталази [мккат·кг ${ }^{1}$ після гострої крововтрати, ускладненої ішемієюреперфузією кінцівки.

За умов гострої крововтрати через 1 год відмічали компенсаторне зростання активності каталази, проте вже з 2 год експерименту активність досліджуваних ензимів знижувалася й досягала мінімуму через 1 добу, в подальшому зростала, проте не досягала рівня контролю. Цілком ймовірно, що у відповідь на гостру крововтрату, в селезінці наростає гіпоксія, що створює передумови для генерації АФО з активацією ферментів антиоксидантної системи. Однак ці процеси характерні для 1 год експерименту. В подальшому досліджені чинники ензимної ланки антиоксидантного захисту знижувалися, що свідчить про їх виснаження і низьку компенсатору здатність антиоксиданого захисту селезінки у відповідь на гостру крововтрату в межах 20-22 \% ОЦК.

Водночас додаткова ішемія-реперфузія кінцівки на тлі гострої крововтрати в селезінці сприяє ще більшому виснаженню СОД і каталази. Починаючи з 1 год експерименту активність цих ферментів стає істотно меншою, порівняно з тваринами дослідної групи, в якій моделювали лише гостру крововтрату. Отриманий результат вказує на те, що має місце нашарування прооксидантних механізмів, зумовлених як гострою крововтратою, так й ішемією-реперфузією кінцівки, і може стати пус- ковим чинником розвитку системної відповіді організму на запалення $[15,16]$ з подальшим поглибленням порушень у селезінці та інших органах.

Застосування карбацетаму суттєво знижувало порушення активності СОД і каталази в селезінці вже після 7-денного застосування. Показники були ще більшими після введення препарату протягом 14 діб, що вказує на виражений протективний вплив карбацетаму на досліджувані чинники антиоксидантного захисту селезінки. Враховуючи дані інших авторів, які вказували на менші порушення ензимної ланки антиоксидантного захисту за умов гострої крововтрати, ускладненої ішемією-реперфузією кінцівки, в печінці [6], легенях [7] та нирці [17] внаслідок застосування карбацетаму можна стверджувати, що карбацетам у досліджуваних експериментальних умовах має виражений антиоксидантний вплив і $\epsilon$ перспективним засобом системної корекції.

Висновки. 1. Двогодинна ішемія кінцівки внаслідок застосування кровоспинного джгута за умов гострої крововтрати істотно поглиблює порушення ензимної ланки антиоксидантного захисту в селезінці у реперфузійному періоді, що виявляється суттєвим зниженням активності СОД і каталази з максимумом через 1 добу, величина 
Огляди літератури, оригінальні дослідження, поглядна якої не повертається до рівня контролю через 14 діб.

2. Уведення карбацетаму протягом 7-14 діб на тлі гострої крововтрати, ускладненої ішемією-реперфузією кінцівки, супроводжується вираженим протекторним впливом на стан ен-

\section{ЛІТЕРАТУРА}

1. Зыблев С. Л. Состояние метаболизма при экспериментальной острой массивной кровопотере в зависимости от проводимой терапии / С. Л. Зыблев, 3. А. Дундаров // Новости хирургии. -2013. - Т. 21, № 5. С. 3-10.

2. Гудима А. А. Антиоксидантно-прооксидантний та цитокіновий баланс у пізній період комбінованої травми в експерименті / А. А. Гудима, Т. В. Кащак, К. В. Шепітько // Світ медицини та біології. - 2019. № 1(67). - C. 42-47.

3. Pathogenetic features of lipid and protein peroxide oxidation due to experimental acute necrotizing pancreatitis / V. V. Maksymyuk, M. I. Sheremet, V. V. Tarabanchuk [et al.] // Archives of the Balkan Medical Union. 2019. - Vol. 54 (2). - P. 235-244.

4. Point of injury tourniquet application during Operation Protective Edge-What do we learn? / A. Shlaifer, A. Yitzhak, E. N. Baruch [et al.] // J. Trauma Acute Care Surg. - 2017. - Vol. 83, Issue 2. - P. 278-283.

5. Максимів Р. В. Динаміка балансу антиоксидантно-прооксидантних механізмів у внутрішніх органах під впливом артеріального джгута і реперфузії кінцівки / Р. В. Максимів, А. А. Гудима, В. М. Сидоренко // Шпитальна хірургія. Журнал імені Л. Я. Ковальчука. -2017. - № 1.C. 37-44.

6. Горбань І. І. Вплив гострої крововтрати, ускладненої ішемією-реперфузією кінцівки, на антиоксидантно-прооксидантний баланс печінки та його корекція карбацетамом / І. І. Горбань // Здобутки клінічної і експериментальної медицини. - 2020. - № 2. - С. 93-100.

7. Стахів О. В. Вплив гострої крововтрати, ускладненої ішемією-реперфузією кінцівки, на активність процесів ліпідної пероксидації у легенях та їх корекція карбацетамом / О. В. Стахів, Р. В. Максимів // Вісник медичних і біологічних досліджень. - 2020. - № 3 (5). С. $108-114$.

8. Яворська І. В. Динаміка активності процесів ліпідної пероксидації в селезінці під впливом гострої крововтрати, ускладненої ішемією-реперфузією кінцівки, та її корекція карбацетамом / І. В. Яворська, І. Я. Гос-

\section{REFERENCES}

1. Zyblev, S.L., \& Dundarov, Z.A. (2013). Sostoyaniye metabolizma pri eksperimentalnoy ostroy massivnoy krovopotere $v$ zavisimosti ot provodimoy terapii [The state of metabolism in experimental acute massive blood loss, depending on the conducted therapy]. Novosti khirurgii Surgery News, 21, 5, 3-10 [in Russian].

2. Hudyma, A.A., Kashchak, T.V., \& Shepitko, K.V. (2019). Antyoksydantno-prooksydantnyi ta tsytokinovyi подарський // Здобутки клінічної і експериментальної медицини. - 2020. - № 4. - С. 178-185.

9. Атлас селезёнки [видовые особенности у человека и млекопитающих животных) : монография / Н. С. Федоровская [и др.]. - Киров : Аверс, 2011. - 134 с.

10. Tourniquets and occlusion: the pressure of design / P. L. Wall, D. C. Duevel, M. B. Hassan [et al.] // Mil. Med. - 2013. - Vol. 178 [5). - P. 578-587.

11. Чевари С. Роль супероксиддисмутазы в окислительных процессах клетки и метод определения ее в биологических материалах / С. Чевари, И. Чаба, Й. Сокей // Лабораторное дело. - 1985. - № 11. - С. 678-681.

12. Метод определения активности каталазы / М. А. Королюк, Л. И. Иванова, И. Г. Майорова, В. Е. Токарев // Лабораторное дело. - 1988. - № 1. - С. 16-19.

13. Comparison of changes in markers of muscle damage induced by eccentric exercise and ischemia/reperfusion / Q. S. Su, J. G. Zhang, R. Dong [et al.] // Scand. J. Med. Sci. Sports. - 2010. - Vol. 20, No. 5. - P. 748-756.

14. Concentration decrease of nitric oxide in the postischemic muscle is not only caused by the generation of O2- / F. Stoffels, F. Lohöfener, M. Beisenhirtz [et al.]. Microsurgery. - 2007. - Vol. 27, No. 6. - P. 565-568.

15. Кузьмінський І. В. Вплив ішемічно-реперфузійного синдрому на активацію системи перекисного окиснення ліпідів у тканині печінки / І. В. Кузьмінський // Клінічна та експерим. патологія. - 2018. № 4 (66). - С. 53-59.

16. Цимбалюк Г. Ю. Стан системи пероксидного окиснення ліпідів у тканині нирки на фоні травми органів черевної порожнини та реперфузії кінцівок / Г. Ю. Цимбалюк // Екстрена медицина: від науки до практики. - 2018. - № 3 (29). - С. 23-32.

17. Шацький В. В. Динаміка антиоксидантно-прооксидантного балансу кіркового і мозкового шарів нирки після гострої крововтрати, ускладненої ішемієюреперфузією кінцівки, та його корекція карбацетамом / В. В. Шацький, А. А. Гудима, Л. Я. Федонюк // Здобутки клінічної і експериментальної медицини. -2019. - № 4. С. 144-153. 
Огляди літератури, оригінальні дослідження, погляд на проблему, випадок з практики, короткі повідомлення peroxide oxidation due to experimental acute necrotizing pancreatitis. Archives of the Balkan Medical Union, 54 (2), 235-244.

4. Shlaifer, A., Yitzhak, A., Baruch, E.N., Shina, A., Satanovsky, A., Shovali, A., \& Glassberg, E. (2017). Point of injury tourniquet application during Operation Protective Edge-What do we learn? J. Trauma Acute Care Surg., 83 (2), 278-283.

5. Maksymiv, R.V., Hudyma, A.A., \& Sydorenko, V.M. (2017). Dynamika balansu antyoksydantno-prooksydantnykh mekhanizmiv u vnutrishnikh orhanakh pid vplyvom arterialnoho dzhhuta i reperfuzii kintsivky [Dynamic of balance of antioxidant-prooxidant mechanism in internal organs Under the influence of blood harnesses and limb reperfusion]. Shpytalna khirurhiia. Zhurnal imeni L. Ya. KovalchukaHospital Surgery. Journal L. Ya. Kovalchuk, 1, 37-44. DOI: 10.11603/2414-4533.2017.1.7637 [in Ukrainian].

6. Horban, I.I. (2020). Vplyv hostroi krovovtraty, uskladnenoi ishemiieiu-reperfuziieiu kintsivky, na antyoksydantnoprooksydantnyi balans pechinky ta yoho korektsiia karbatsetamom [The effect of acute blood loss complicated by limb ischemia-reperfusion on the antioxidant-prooxidant balance of the liver and its correction by carbacetam]. Zdobutky klinichnoi i eksperymentalnoi medytsyny-Achievements of Clinical and Experimental Medicine, 2, 93-100. DOI: https://doi. org/10.11603/1811-2471.2020.v.i2.11320 [in Ukrainian].

7. Stakhiv, O.V., \& Maksymiv, R.V. (2020). Vplyv hostroi krovovtraty, uskladnenoi ishemiieiu-reperfuziieiu kintsivky, na aktyvnist protsesiv lipidnoi peroksydatsii u leheniakh ta yikh korektsiia karbatsetamom [Influence of acute blood loss complicated by limb ischemia-reperfusion on the activity of lipid peroxidation processes in lungs and their correction with carbacetam]. Visnyk medychnykh i biolohichnykh doslidzhen - Bulletin of Medical and Biological Research, 3 (5), 108-114. DOI: 10.11603/bmbr.2706-6290.2020.3.11525 [in Ukrainian].

8. Yavorska, I.V., \& Hospodarsky, I.Ya. (2020). Dynamika aktyvnosti protsesiv lipidnoyi peroksydatsiyi v selezintsi pid vplyvom hostroyi krovovtraty, uskladnenoyi ishemiyeyureperfuziyeyu kintsivky, ta yiyi korektsiya karbatsetamom [Dynamics of activity of lipid peroxidation processes in the spleen under the influence of acute blood loss, complicated by ischemiareperfusion of the limb and its correction with carbacetam]. Zdobutky klinichnoi i eksperymentalnoi medytsyny - Achievements of Clinical and Experimental Medicine, 4, 178-185. DOI: 10.11603/1811-2471.2020.v.i4.11771 [in Ukrainian].

9. Fedorovskaya, N.S. (2011). Atlas selezonki (vidovyye osobennosti u cheloveka i mlekopitayushchikh zhivotnykh): monografiya [Atlas of the spleen (specific features in humans and mammals): monograph]. Kirov: Avers [in Russian].

10. Wall, P.L., Duevel, D.C., Hassan, M.B., Welander, J.D., Sahr, S.M., \& Buising, C.M. (2013). Tourniquets and occlusion: the pressure of design. Mil. Med., 178 (5), 578-587. DOI: 10.7205/MILMED-D-12-00490

11. Chevari, S., Chaba, I., \& Sokey, Y. (1985). Rol superoksiddismutazy $v$ okislitelnykh protsessakh kletki i metod opredeleniya yeye $v$ biologicheskikh materialakh [The role of superoxide dismutase in the oxidative processes of the cell and the method for its determination in biological materials]. Labolatornoye delo - Laboratory Work, 11, 678-681 [in Russian].

12. Korolyuk, M.A., Ivanova, L.I., Mayorova, I.G., \& Tokarev, V.Ye. (1988). Metod opredeleniya aktivnosti katalazy [Method for determining the activity of catalase]. Labolatornoye delo - Laboratory Work, 1, 16-19 [in Russian].

13. Su, Q.S., Zhang, J.G., Dong, R., Hua, B., \& Sun, J.Z. (2010). Comparison of changes in markers of muscle damage induced by eccentric exercise and ischemia/reperfusion. Scand. J. Med. Sci. Sports., 20 (5), 748-756. DOI: 10.1111/ j.1600-0838.2009.01015.x

14. Stoffels, F., Lohöfener, F., Beisenhirtz, M., Lisdat, F., \& Büttemeyer, R. (2007). Concentration decrease of nitric oxide in the postischemic muscle is not only caused by the generation of O2-. Microsurgery, 27 (6), 565-568. DOI: 10.1002/micr.20403

15. Kuzminskyi, I.V. (2018). Vplyv ishemichno-reperfuziinoho syndromu na aktyvatsiiu systemy perekysnoho okysnennia lipidiv u tkanyni pechinky [Influence of ischemic-reperfusion syndrome on activation of lipid peroxidation system in liver tissue]. Klinichna ta eksperym. patolohiia-Clin. Exp. Pathol., 4 (66), 53-59 [in Ukrainian].

16. Tsymbaliuk, H.Yu. (2018). Stan systemy peroksydnoho okysnennia lipidiv u tkanyni nyrky na foni travmy orhaniv cherevnoi porozhnyny ta reperfuzii kintsivok [The state of the system of peroxide oxidation of lipids in kidney tissue on the background of trauma of the abdominal cavity and reperfusion of the extremities]. Ekstrena medytsyna: vid nauky do praktyky - Emergency Medicine: From Science to Practice, 3 (29), 23-32 [in Ukrainian].

17. Shatsky, V.V., Gudyma, A.A., \& Fedoniuk, L.Ya. [2019). Dynamika antyoksydantno-prooksydantnoho balansu kirkovoho i mozkovoho shariv nyrky pislia hostroi krovovtraty, uskladnenoi ishemiieiu-reperfuziieiu kintsivky, ta yoho korektsiia karbatsetamom [Dynamics of antioxidant-prooxidant balance of renal cortex and medulla after acute blood loss complicated by ischemia-reperfusion of the extremity, and its correction with carbacetam]. Zdobutky klinichnoi i eksperymentalnoi medytsyny - Achievements of Clinical and Experimental Medicine, 4, 144-153. DOI: 10.11603/1811-2471.2019.v.i4.10815 [in Ukrainian]. 
Огляди літератури, оригінальні дослідження, погляд на проблему, випадок з практики, короткі повідомлення

\title{
ВЛИЯНИЕ ОСТРОЙ КРОВОПОТЕРИ, ОСЛОЖНЕННОЙ ИШЕМИЕЙ-РЕПЕРФУЗИЕЙ КОНЕЧНОСТИ, НА ДИНАМИКУ ПОКАЗАТЕЛЕЙ ЭНЗИМНОГО ЗВЕНА АНТИОКСИДАНТНОЙ ЗАЩИТЫ В СЕЛЕЗЕНКЕ И ЕЕ КОРРЕКЦИЯ КАРБАЦЕТАМОМ
}

() И. В. Яворская

\author{
Тернопольский национальный медицинский университет имени И. Я. Горбачевского МОз Украины
}

РЕзЮМЕ. Нарушение энзимного звена антиоксидантной защиты относится к одному из ключевых патогенных механизмов поражения внутренних органов в условиях острой кровопотери и ишемично-реперфузионного синдрома. Однако нарушение активности супероксиддисмутазы (СОД) и каталазы в условиях острой кровопотери и ее осложнения ишемией-реперфузией конечности в селезенке практически не исследованы. Нет данных о6 эффективности в этих условиях карбацетама, который обладает антиоксидантной и тканепротективной активностью.

Цель - выяснить особенности нарушений показателей энзимного звена антиоксидантной системы в селезенке крыс после острой кровопотери, осложненной ишемией-реперфузией конечности, и эффективность ее коррекции карбацетамом.

Материал и методы. В экспериментах использовано 108 нелинейных крыс-самцов массой 200-220 г. Все эксперименты выполнены под тиопентал-натриевым наркозом. У животных моделировали ишемию-реперфузию конечности, острую кровопотерю и сочетали эти повреждения. В отдельной группе проводили коррекцию выявленных нарушений карбацетамом. Через 1 и 2 часа, а также через 1, 7 и 14 суток в селезенке подопытных животных определяли активность СОД и каталазы.

Результаты. Моделирование острой кровопотери, осложненной ишемией-реперфузией конечности, в селезенке способствует наибольшему истощению СОД и каталазы. Начиная с 1 ч эксперимента активность этих ферментов становится существенно меньше, по сравнению с животными исследовательской группы, в которой моделировали только острую кровопотерю. Применение карбацетама существенно снижало нарушение активности СОД и каталазы в селезенке уже после 7-дневного применения. Показатели были еще большими после введения карбацетама в течение 14 суток, что указывает на выраженное протективное влияние препарата на исследуемые факторы антиоксидантной защиты селезенки и является перспективным средством системной коррекции.

Выводы. 1. Двухчасовая ишемия конечности вследствие применения кровоостанавливающего жгута в условиях острой кровопотери способствует существенному снижению активности СОД и каталазы в селезенке с максимумом через 1 сутки, величина которой не возвращается к уровню контроля через 14 суток. Введение карбацетама течение 7-14 суток сопровождается выраженным протекторным влиянием на состояние энзимного звена антиоксидантной защиты селезенки.

КЛЮчЕВЫЕ СЛОВА: острая кровопотеря; ишемия-реперфузия конечности; селезенка; супероксиддисмутаза; каталаза; карбацетам.

\section{INFLUENCE OF ACUTE BLOOD LOSS COMPLICATED BY LIMB ISCHEMIA-REPERFUSION ON THE DYNAMICS OF ENZYME LINKS OF ANTIOXIDANCE ZADACANT}

๑) I. V. Yavorska

\section{Horbachevsky Ternopil National Medical University}

SUMMARY. Violation of the enzymatic link of antioxidant protection belongs to one of the key pathogenic mechanisms of damage to internal organs in conditions of acute blood loss and ischemic-repefusion syndrome. However, disorders of superoxide dismutase [SOD) and catalase in acute blood loss and its complications by ischemia-reperfusion of the limb in the spleen have not been studied. There are no data on the effectiveness under these conditions of carbacetam, which has antioxidant and tissue-protective activity.

The aim - to find out the features of disorders of the enzyme link of the antioxidant system in the spleen of rats after acute blood loss complicated by ischemia-reperfusion of the limb, and the effectiveness of its correction by carbacetam.

Material and Methods. 108 nonlinear male rats weighing 200-220 g were used in the experiments. All experiments were performed under thiopental-sodium anesthesia. In animals, limb ischemia-reperfusion and acute blood loss were simulated and these lesions were combined. In a separate group, the detected disorders were corrected with carbacetam. After 1 and 2 hours, as well as after 1, 7 and 14 days in the spleen of experimental animals, the activity of SOD and catalase was determined.

Results. Simulation of acute blood loss complicated by ischemia-reperfusion of the limb in the spleen contributes to the greatest depletion of SOD and catalase. Starting from $1 \mathrm{~h}$ of the experiment, the activity of these enzymes 
Огляди літератури, оригінальні дослідження, погляд на проблему, випадок з практики, короткі повідомлення becomes significantly lower compared to animals in the experimental group, which simulated only acute blood loss. The use of carbacetam significantly reduced the activity of SOD and catalase in the spleen after 7 days of use. The rates were even higher after the introduction of carbacetam for 14 days, which indicates a pronounced protective effect of the drug on the studied factors of antioxidant protection of the spleen and is a promising means of systemic correction.

Conclusions. 1. Two-hour ischemia of the limb due to the use of a tourniquet in acute blood loss contributes to a significant decrease in the activity of SOD and catalase in the spleen with a maximum after 1 day, the value of which does not return to the control level after 14 days. Administration of carbacetam for 7-14 days is accompanied by a pronounced protective effect on the enzyme level of antioxidant protection of the spleen.

KEY WORDS: acute blood loss; ischemia-reperfusion of the limb; spleen; superoxide dismutase; catalase; carbonate.

Отримано 22.04.2021 